\title{
Idearios de género para la modernidad limeña finisecular en dos cuentos de Clorinda Matto de Turner
}

\author{
A Gender Philosophy for Lima's Modernity in Two Short Stories by \\ Clorinda Matto de Turner \\ Elena Grau-Lleveria \\ University of Miami, Florida, Estados Unidos \\ Contacto: e.graulleveria@miami.edu \\ https://orcid.org/0000-0001-7156-6368
}

\begin{abstract}
Resumen
Al conjugar parte de la extensa bibliografía sobre la producción literaria de Clorinda Matto de Turner con un marco ideológico feminista, este artículo examina el ideario de género que se construye con relación a la modernidad, a las políticas de género y a los imaginarios nacionales en dos de sus cuentos: "Pálida!... pero es ella...! Novela homeopática con pretensiones espiritistas" y "Amor de redondel. Cuento a modo de novela". Dicho ideario, superficialmente, presenta inestabilidades y contradicciones. Sin embargo, es a través de estas aparentes contradicciones que Matto de Turner pudo gestionar su ideario de reforma de políticas de género y de refundación nacional sin aparentemente alterar la norma hegemónica.

Palabras clave: Clorinda Matto de Turner; Feminismo; Modernidad; Políticas de género; Nación.
\end{abstract}

\begin{abstract}
Combining part of the extensive literature on the literary production of Clorinda Matto de Turner with a feminist ideological framework, this article examines the ideology of gender constructed in relation to modernity, gender policies and national imaginary in two of his short stories, "Pálida!... pero es ella...! Novela homeopática con pretensiones espiritistas" and "Amor de redondel. Cuento a modo de novela". This ideology, superficially, presents instabilities and contradictions. However, it is through these apparent contradictions that Matto de Turner could manage her reformist program around gender and national reform without apparently altering the hegemonic rule.
\end{abstract}

Keywords: Clorinda Matto de Turner; Feminism; Modernity; Gender politics; Nation.

Recibido: 01.02.19

Aceptado: 15.05.19 
No podemos convenir en la existencia del ateo, pues no creemos

haber llegado al siglo de los hombres descorazonados.

(Matto de Turner, 1893)

La bibliografía sobre la obra y la figura de Clorinda Matto de Turner (1852-1909) es actualmente extensa. Especialmente se han trabajado sus tres novelas - Aves sin nido (1889) ${ }^{1}$, Índole (1891) y Herencia (1893) —, las tradiciones y leyendas de tema indigenista, los ensayos donde ella aborda la cuestión femenina (Ferreira, 2004), lo que Mary Louise Pratt (1995) denominó ensayo de género² y su propia persona en tanto que periodista, novelista y editora ${ }^{3}$. También recientemente se ha prestado atención a su libro de viajes ${ }^{4}$. Sin embargo, son pocos los estudios sobre los cuentos de temática no indígena. Excepción a esta carencia bibliográfica son los trabajos de Marcel Velázquez Castro (2012; 2017), quien considera que esta parte de su producción literaria es, desde la perspectiva de las técnicas narrativas:

[e]1 más complejo y moderno de la prosa narrativa de Matto. En varios relatos, el narrador no juzga ni valora lo ocurrido en la trama, sino que se limita a contar e ingresa, sin preámbulos, al universo ficcional. Aunque se mantiene la forma típica del narrador decimonónico, es decir, el omnisciente, los personajes adquieren mayor singularidad y autonomía. (Velázquez Castro, 2017, p. 141)

Del conjunto de estudios sobre la obra de esta autora con que he trabajado, es relevante destacar que la mayoría de ellos subrayan, desde distintas perspectivas y sensibilidades ideológicas ${ }^{5}$, el compromiso de Matto de Turner con la regeneración de la sociedad peruana. A tal propósito, María Caballero Wangüemert (1993) rechaza la división que la crítica había consolidado antes de la década de 1990, donde las leyendas y los cuentos eran considerados de talante romántico-idealista ${ }^{6}$, mientras que sus novelas se insertaban en una tendencia social realista con algunos rasgos naturalistas pero también melodramáticos, como bien argumenta Joan Torres-Pou (1990). Para Caballero Wangüemert (1993), toda la producción de Matto de Turner "se sostiene en una misma inquietud moral" (p. 163), cuyo fin es dar a su público lector un conjunto de valores morales con los 
que refundar la nación peruana. En una línea de análisis crítico-teórico de estudios de género con una clara ideología feminista, Ana Peluffo (2005), conceptualiza y analiza la retórica del sentimentalismo como la técnica discursiva, a la vez que la estrategia ideológica, con la que esta escritora articula su ideario político de reforma social (y sociosexual). A tal propósito, Peluffo (2005) argumenta que

[...] el sentimentalismo, entendido como un deseo de hacerle derramar lágrimas al lector por la suerte de un Otro-étnico en peligro, es un ingrediente fundamental de la visión política que tiene Matto de Turner de la novela como órgano de reforma socio-cultural. (p. 21)

Es esta misma retórica del sentimentalismo la que enmascara los discursos descentralizadores de un conjunto de discursos hegemónicos en "Pálida!... pero es ella...! Novela homeopática con pretensiones espiritistas" y en "Amor de redondel. Cuento a modo de novela"7. La retórica del sentimentalismo en estas dos narraciones se sostiene en una sensibilidad emocional que hace que el público lector se identifique con aquellos personajes que actúan para obtener una meta, que es presentada por la ideología textual dominante como buena y deseable. Así, Matto de Turner desdibuja las implicaciones ideológicas de los actos de esos personajes. Con ello, esta escritora consigue que el público lector suspenda potenciales juicios de valor sobre los medios y procesos que se ponen en escena. En dicho aspecto de estos cuentos es donde reside esa productiva indefinición ideológica tan propia de la producción de esta escritora, la cual Peluffo (2007), describe de la siguiente manera:

Se podría pensar en los textos de Matto de Turner como en artefactos culturales amalgamados o "totalidades contradictorias" para citar una frase de Cornejo Polar, en los que se entrecruzan ideologías opuestas: no solamente en términos etnográficos, entre indigenismo e indianismo; o en términos de género, entre un discurso que enfatiza la diferencia o la igualdad; sino también entre cristianismo y positivismo. (p. 215)

Si esta inestabilidad ideológica, aunada al sentimentalismo, se toma como una de las estrategias que le permitió a Matto de Turner desdibujar y 
enmascarar las subversiones a los discursos hegemónicos, es preciso analizar cómo se generan estas tensiones, cómo se inscriben, qué subversiones producen y qué relación mantienen con los distintos discursos de poder-verdad que altera $\left(\right.$ Foucault, 2007) ${ }^{8}$. Las respuestas a estas preguntas ayudan a pensar y a gestionar los potenciales significados ideológicos feministas de estos cuentos. Si bien es preciso subrayar que las inestabilidades ideológicas presentes en la creación de Matto de Turner deben entenderse no como un rasgo particular de esta autora, sino como característica común a las escritoras y escritores del entre siglos decimonónico que tiene, claro está, variantes artístico-ideológicas y de género.

Desde este marco literario-cultural, el análisis que elaboro de estos dos textos está encaminado a preguntarse por los significados y posibilidades sociosexuales que se producen respecto a la modernidad y a las políticas de género que esta debe tener según el imaginario ideal de Matto de Turner. La modernidad en estos textos se proyecta múltiple y móvil, como los individuos que en ella viven o que a ella se incorporan. Desde esta multiplicidad, ambos cuentos ponen de manifiesto las revisiones que esta autora propuso a los discursos hegemónicos de género, a las tendencias ideológicas artísticas del momento, especialmente al modernismo, y las correcciones que formuló a la cosmovisión positivista y al ideario católico. Todo ello se entrelaza con la voluntad de proponer modelos de comportamiento que revisen las políticas de género existentes en aras de promover una refundación nacional. De ahí que los personajes de "Pálida!" y "Amor de redondel" devengan tipos que representan metonímicamente a colectivos nacionales determinados. Dichos personajes tipo están dotados de un contenido alegórico nacional, que responde tanto a los complejos entramados sociales de Lima como a la heterogeneidad de su modernidad ${ }^{9}$. Lo significativo del uso de un prototipo nacional-cultural se halla en la alteración que se produce al modelo del que se parte. En tal sentido, Matto de Turner conjuga un proyecto de narración de los procesos nacionales-limeños de modernización con un programa moral y sociosexual que ${ }^{10}$, soterradamente, inscribe unas prácticas y actitudes propias de la modernidad deseada por la autora, la cual no es coincidente con la ostentada por los grupos hegemónicos. 
De acuerdo con lo planteado, en "Pálida!" se va a revisar y alterar un conjunto de procesos simbólicos directamente relacionados con la modernidad urbana, literaria, cultural y con las éticas de las feminidades y masculinidades del entre siglos decimonónico. En este cuento se nos narra la historia de Aurelio, que asiste a los últimos momentos de vida de Esperanza, su enamorada. En el lecho de muerte, esta quiere que él tenga el único retrato que se hizo hacer para que sea su guía y le sostenga la fe en la vida, en Dios (en el contexto son sinónimos), hasta el momento en que encuentre a otra mujer a la que amar. Esperanza muere pero Aurelio no obtiene el retrato porque la madre de Esperanza se lo había llevado antes. A partir de este momento, la narración elabora el estado de apatía y desesperanza en que se encuentra Aurelio. Dicha situación cambia cuando este entrevé la posibilidad de lograr el tan anhelado retrato de Esperanza gracias a los avances científicos de la fotografía, a la que se dedica con devoción y pasión hasta lograr la imagen del espíritu de Esperanza, lo que le devuelve la fe en la vida-dios.

La riqueza temática de este texto, desde el imaginario simbólico del entre siglos, es sorprendente. En la primera instancia del cuento, Matto de Turner incursiona en la tradición de la bella joven a punto de morir ${ }^{11}$. No se trata entonces del típico cuadro que los artistas modernistas estaban consolidando como topo sociosexual en este mismo momento, donde la contemplación de la bella enferma y su muerte era un mero recurso para la elaboración de una subjetividad masculina. En la escena — que no cuadro - que crea Matto de Turner, lo primero que llama la atención es que la descripción se hace desde la voz narrativa y el protagonismo que esta le concede al estado vital de la enferma, lejos de ser una bella estatua, es un cuerpo-conciencia que sufre; ello puede verse en la siguiente cita:

En la blanquísima cama que luce los encajes y las blondas encarrujadas por las delicadas manos de una mujer, está demacrada y triste, mi bella Esperanza, con la cabellera suelta, la cabeza colocada sobre almohadones de diferentes tamaños, los brazos extendidos sobre el tapador y los ojos entreabiertos al sopor de quien dormita soñando entre el cielo y la tierra. (Matto de Turner, 1893, p. 57) 
Para entender las inestabilidades de este escenario respecto al canonizado por la tradición literaria, que es el modernista masculino, es importante prestar atención a la adjetivación de que es objeto Esperanza por parte de la voz narrativa. Desde su visualidad, Esperanza deviene un ser activo en su tristeza y en su estado de febril ensoñación. De la misma manera, la visión que se ejerce sobre ella, al señalar los estragos que la enfermedad le ha provocado, si no la afea, tampoco la embellece. Las imágenes disruptivas respecto al imaginario modernista se amplían al convertir a Aurelio en la "estatua del desfallecimiento" (Matto de Turner, 1893, p. 60). Es más, la inversión de las imágenes de género propias del discurso de la bella muerta se complementa con la inscripción de una sentimentalidad masculina, la de Aurelio, en la que no se privilegia un discurso estético-ideológico, la belleza "perfecta" de la joven a punto de morir, sino los sentimientos de amor que esta le transmitía cuando estaba sana. Es decir, no es él quien elabora su subjetividad masculina a través del discurso de la bella muerta, sino que Aurelio es el intermediario por el que se da a conocer la personalidad de una Esperanza saludable. Con ello se crea una imagen de una feminidad emocional y eróticamente activa: "Fría!... insensible! ¿en dónde está el calor que ayer nomás agitaba tu corazón? ¿Dónde la nerviosidad que estremecía tu mano al contacto de la mía?... también tu alma Esperanza mía, está yerta al roce de mi alma?" (Matto de Turner, 1893, p. 59).

La revisión y alteración simbólica del discurso de la bella muerta dan lugar a unos procesos de reforma nacional y sociosexual que se plantean desde la voz y visión de mundo de Esperanza. Es esta quien, en sus últimos momentos de vida, se inscribe a sí misma como la regeneradora de la masculinidad apática, descreída y descorazonada en la que se posiciona Aurelio ante la pronta muerte de su amada. Ella desea que Aurelio llegue a ser un buen compañero para otra mujer y un ciudadano activo y productivo para su país. Para ello debe tener fe en la vida-dios y en las posibilidades de obtener lo que desea si trabaja (cree) en ello. Es decir, en esta escena, la bella muerta — producto del simbolismo masculinodesaparece para convertirse en una feminidad social y éticamente activa que 
concibe y verbaliza la masculinidad que desea para ella, para otras mujeres y para la nación. Estos procesos de reinscripción simbólica desafían, además, el catolicismo tradicional. En la espiritualidad que le propone Esperanza a Aurelio no se mencionan rituales religiosos y no existen intermediarios, todo el poder recae en la voluntad de la persona. Por ello, la fe religiosa de la que se envuelve Esperanza es y enmascara un ideario ético-espiritual laico de ser y estar en lo social-nacional. De ahí que "las pretensiones espiritistas" que forman parte del título del cuento remitan tanto al proceso de crisis espiritual de Aurelio como a la agenda regeneradora que propone Esperanza, a la vez que remiten a una forma de religiosidad distinta a la del dogma católico.

Con todo, el papel de Esperanza sigue siendo el de mediadora para la configuración de la masculinidad ideal, si bien es cierto también que es una mujer la que actúa como ideóloga del programa de reforma nacional. Lo que está en juego en el análisis y la teorización feminista de un personaje como Esperanza es mostrar cómo Matto de Turner la dota de nuevos agenciamientos ideológicos y estéticos que modifican los imaginarios sobre las masculinidades y feminidades hegemónicas, sean estas modernistas, tradicionales o positivistas. En Esperanza hay una apuesta por una modernidad híbrida, en apariencia respetuosa con los códigos sociosexuales, que sin embargo negocia un espacio distinto para las mujeres de su clase del que se le asigna en los discursos de poder-verdad del modernismo, positivismo y catolicismo.

Desde esta perspectiva, solo las parejas de iguales, si bien diferentes en la lógica de la complementariedad de sexos, pueden llevar a cabo la refundación de los valores ético-nacionales. Ello significa, entre otras cosas, un claro desacuerdo con las masculinidades que privilegiaban los escritores modernistas. En "Pálida!", la crítica a este tipo de masculinidades se inicia en el siguiente apartado temporal del cuento, cuando Aurelio se ha convertido en el prototipo de masculinidad indeseado por Esperanza ${ }^{12}$. Este vaga por una Lima en plena efervescencia de transformación urbana, con parques recién remodelados, edificios modernos que albergan nuevos espacios de socialización, con calles llenas de automóviles y 
tranvías, sin ningún interés, sin motivación, ajeno a todo y sin participar en nada. Se ha convertido en un descreído, en un ateo ${ }^{13}$. Es la masculinidad que ha perdido la fe del letrado, esa que imaginaba la posibilidad del cambio social por medio de la actuación individual-grupal. Aurelio representa esa masculinidad moderna que se define por su descreimiento, apatía y cinismo. Es este descreimiento lo que lleva a estos hombres a aislarse del mundo exterior a quien culpan de no poder conseguir sus ideales. Esta masculinidad alude a la que se inscribe en numerosas novelas modernistas de autoría masculina, como dije anteriormente. Ahora bien, si la modernidad produce esta masculinidad indeseable, desde la ideología sociosexual de Esperanza también es la modernidad la que proporciona los espacios reales y simbólicos para su regeneración. Esta otra cara de la modernidad se enlaza con las nuevas posibilidades de conocimiento y de acción social que ofrece el avance de las ciencias, en específico la fotografía y la creación del foto-club. Espacio, este último, que como la nación deseada está constituido por un colectivo de verdadero espíritu liberal que "[...] respeta las convicciones agenas y no exige más que estudio y progreso en el arte fotográfico" (1893, p. 62). El foto-club, en tanto que espacio real-ideal nacional, es la tercera instancia ideológica del texto. En este apartado, Matto de Turner elabora un complejo juego ideológico donde se van a combinar, que no a tensionar, la ciencia con el espiritualismo. A tal propósito Velázquez Castro (2012) propone que:

[...] la fotografía, elemento de la modernización tecnológica, queda ligada al progreso y a la ciencia (representada por las figuras de los médicos); pero cumple una ambigua función en la trama, ya que permite la reconciliación con la divinidad del protagonista. Estas estructuras narrativas, ideológicamente heterogéneas, formalizan la experiencia multitemporal de la narradora cuzqueña. (p. 143)

Las imágenes que genera esta tercera parte del cuento remiten a un modelo de masculinidad que si bien ha hecho suyo el proyecto del avance científico la ideología positivista-, este se ve dislocado porque se aúna a una búsqueda espiritual. En una sorprendente apropiación de los regímenes discursivos de las experiencias existenciales de los personajes modernistas, Matto de Turner 
convierte el laboratorio fotográfico, donde trabaja Aurelio, en una especie de torre de marfil, de paraíso artificial, cuya finalidad es conseguir la gran obra: plasmar en fotografía el alma de Esperanza. En este proyecto se entrecruzan lo morboso y lo ideal, las búsquedas artístico-científicas con las espirituales como en los protagonistas modernistas. Y como estos, Aurelio se entrega "devotamente" a la culminación de su proyecto (López Martín, 2007, p. 42). Es aquí donde la narración adquiere tonos propios de lo fantástico, si bien se invierten los valores hegemónicos que tiene este género en el siglo XIX.

En lo fantástico decimonónico lo sobrenatural desdibuja las certezas epistemológicas y puede causar al sujeto pánico y ansiedad (Clúa Ginés, 2014, p. 962). Por el contrario, en "Pálida!", la presencia del elemento fantástico es el medio para sanar a Aurelio de su cinismo y descreimiento (de ahí el subtítulo de “cuento homeopático"). Es más, si lo fantástico decimonónico forma parte de la constelación con que se crean los imaginarios de crisis espirituales e intelectuales que se entrelazan con los imaginarios ideológicos positivistas (López Martín, 2007 , p. 44), en este cuento constituyen el proceso por el que el protagonista supera dichas crisis ${ }^{14}$. Ahora bien, cabe preguntarse si este texto es realmente fantástico ${ }^{15}$. Estrictamente hablando, "Pálida!" no es un cuento fantástico. Sin embargo, Matto de Turner se apropia de algunos de sus elementos, si bien los transforma de signo ideológico. Con ello subvierte el subgénero narrativo o el discurso de poder-verdad del cuento fantástico decimonónico al que parece adscribirse el cuento. De hecho, Matto de Turner no solo coquetea con el género fantástico (al presentar un deseo-obsesión imposible que nos remite a las distintas quimeras pseudocientíficas tan propias de lo fantástico en el siglo XIX), sino que se apropia de temas procedentes del gótico como la necrofilia, el ocultismo y el espiritismo; los somete, así, a un proceso de "saneamiento" desde la perspectiva ideológica textual dominante, puesto que la búsqueda espiritual de Aurelio no solo se presenta como justa sino también deseable, tanto en el ámbito individual como nacional. A la vez, los procesos que este utiliza son científicos. De ahí que, desde la visualidad narrativa, el triunfo espiritual-científico de Aurelio, el conseguir plasmar en fotografía el alma de su amada, sea también considerado un 
avance para la nación. En esta torsión ideológica, que aúna ciencia, espiritualidad, masculinidad ideal y nación, Matto de Turner ha elaborado una narración donde discursos frontalmente contrapuestos se asocian para ofrecer un proyecto nacional ${ }^{16}$.

Llegados a este punto cabe preguntarse qué ha conseguido ideológicamente este texto respecto a las preguntas que planteaba al inicio. En primer lugar, pone en boca de la mujer el ideario de reforma nacional que se simboliza por el deseo de regenerar una masculinidad descreída, a la vez que propone un imaginario de parejas heterosexuales, de iguales sentimental y éticamente. En segundo lugar, resignifica una serie de enclaves ideológicos característicos de los discursos de verdad-poder del momento, como son las crisis masculinas finiseculares, el agnosticismo positivista y la reformulación de la distopía del género fantástico en una utopía individual con incidencia en lo nacional que, indirectamente, desarticula las representaciones de feminidad usadas como símbolos de los deseos y miedos masculinos; a su vez, propone una masculinidad acorde con los deseos de un grupo de mujeres de clase mediaalta representadas metonímicamente por Esperanza. La desestabilización y resignificación de dichos discursos hegemónicos se hace posible gracias al concepto de modernidad que permea el texto. Es decir, la modernidad actúa en pro de la reforma nacional-sociosexual creando la posibilidad de la subversión ideológica de aquellos discursos que, por modernos que sean, impiden, según la ideología textual, la regeneración nacional.

Bien distinto a "Pálida!" es "Amor de redondel". En este cuento se nos narra la trayectoria vital de Francisco Ccolqque, un serrano aparentemente mestizo que aspira a convertirse en un famoso torero en Lima. El texto presenta una particular narración de crecimiento y triunfo profesional donde el protagonista, a medida que consigue lo que desea, va modificando su nombre, a la vez que altera su identidad cultural. Sin embargo, la trama de ascensión social como torero se suspende cuando aparece otro hilo argumental: el amor que este siente por una limeña, Paulina Laredo, de clase social superior a la suya y de quien se enamoró el primer día que toreó y triunfó en la plaza de Acho. Francisco Ccolqque, ahora 
Paco de Plata, consigue el amor de Paulina Laredo gracias a un intento de suicidio público por amor, pues a propósito se deja cornear por un toro.

Respecto a este final, Velázquez Castro (2012) propone una interpretación que se encuentra en consonancia con la idealización de la modernidad limeña que parece ostentar el texto al afirmar que "[e]l desenlace prueba que la unión interclasista es posible y que el mestizo andino, en situaciones excepcionales, puede conquistar su objeto de deseo. En este texto, se manifiesta una imagen idealizada de Lima y angelical de la mujer limeña" (p. 142). Sin contradecir la interpretación de este autor, propongo un análisis teórico-cultural de "Amor de redondel" donde expongo cómo las tensiones ideológicas funcionan como la estrategia que desdibuja la crítica y reforma social que contiene esta narración, al mismo tiempo que enmascara la modernidad sociosexual deseada. Para ello analizo los tres aspectos que funcionan como sinécdoque de tipos e imaginarios nacionales: Lima (nación), Francisco Ccolqque-Paco de Plata (la inmigración andina a Lima y una forma de masculinidad) y Paulina Laredo (las limeñas y la formulación de una feminidad moderna) $)^{17}$. Si en "Pálida!" el sujeto-objeto a reformar era una masculinidad apática, en "Amor de redondel" la crítica y reforma sociosexual se amplía también a ciertas feminidades y a la modernidad limeña que se presenta bajo un prisma mucho más complejo y ambiguo que en el cuento anterior.

Al abordar el análisis de la multiplicidad de miradas sobre Lima en este cuento, es preciso subrayar la inestabilidad ideológica que se inscribe sobre esta ciudad y el efecto caleidoscópico que produce ${ }^{18}$. El collage de imágenes es una de las estrategias que Matto de Turner pone en juego para encubrir la crítica social y sociosexual que está llevando a cabo sobre lo que se podría denominar, siguiendo cierta terminología de época, el espíritu limeño. Las visiones a que hago referencia son la de Francisco Ccolqque, la de Lima misma y la de la voz narrativa. Para el protagonista, Lima es “[...] placer, ventura, contento, nombradía, gloria y fortuna" (Matto de Turner, 2015, p. 148). En aparente consonancia con la visualidad que sobre Lima ejerce Francisco Ccolqque, Lima se ve a sí misma como el espacio de la felicidad y el placer (Matto de Turner, 2015, p. 149). En esta Lima desaparece 
toda referencia a la posibilidad de triunfo individual por medio del trabajo y la voluntad, que es la ideología en que se sustenta la representación de la capital peruana elaborada por el protagonista. Es decir, Lima no se concibe a sí misma como un lugar donde el trabajo lleva al triunfo (ideario del inmigrante), sino como un espacio de diversión perpetua.

En tensión con estas dos visiones, la voz narrativa, con un tono de aparente jovialidad y alegría, como si estuviera contagiada del festivo espíritu limeño, presenta una Lima superficial y volátil. Así, muestra distintas caras de la ciudad a través de diferentes objetos que visualiza desde su perspectiva ideológica. Una de las primeras imágenes-imaginarios que presenta es la concepción que tiene de limeños y limeñas. Para ello utiliza la reacción de este colectivo ante los aparentemente frecuentes suicidios de extranjeros (gringos) y chinos que viven en Lima ${ }^{19}$. Este giro visual-emocional -imágenes es lo que produce esta narración - lleva al público lector a la confrontación con un fenómeno social tan problemático, desde las ideologías católica, positivista y krausista, como lo es el suicidio. Suicidios provocados por una Lima que no cumple las promesas que albergan los inmigrantes que a ella llegan. Ahora bien, esta crítica a la superficialidad limeña pasa desapercibida parcialmente debido a la rapidez con que se suceden las distintas imágenes y concepciones sobre Lima, por un lado, y, por otro, a la ausencia de explicación y juicio del porqué de estos suicidios. De acuerdo con lo hasta aquí planteado, la dislocación entre la retórica de la jovialidad y el contenido trágico que la voz narrativa establece es lo que da una entrada difuminada a la cara oscura de esa Lima moderna que se quiere y que vive enamorada de su espíritu festivo y banal ${ }^{20}$.

La anterior cadena simbólica se complica en el momento que la voz narrativa crea una analogía entre Lima y sus mujeres. Esta instancia narrativa amplía las contradicciones que contiene dicha ciudad, la cual es como

[s]us mujeres sueñan en un campo cuyos matices se alternan, confundidos muchas veces, lo serio y lo superfluo.

La limeña es grande, heroica, si se trata de acciones elevadas y nobles; es niña cuando desciende al nivel de las pequeñeces de la vida. (Matto de Turner, 2015, p. 149) 
Las operaciones de reajuste y ensamblaje sobre Lima vuelven a ampliarse cuando la plaza de Acho es el espacio metonímico que muestra otra forma de ser limeña, la del pueblo. Desde la visión de la voz narrativa, la plaza de Acho (Lima) se convierte en la "Babilonia del entusiasmo" (Matto de Turner, 2015, p. 150). Esta expresión podría entenderse de muchas maneras, sin embargo la posterior elección de la voz narrativa de equiparar la plaza de toros a un circo, con claras referencias a los espectáculos romanos, a la vez que optar, en el título del cuento ${ }^{21}$, por redondel en vez del nombre del oficio de Francisco Ccolqque-Paco de Plata, crea un tono satírico, cómico que está en consonancia con la visualidad de la narración intradiegética. En tal sentido, el título del cuento amplía las visiones sobre el ser y estar limeño, ya que añade esa manera de ser nacional que crea una parodia o chiste a partir de cualquier situación. Esta forma de alteración, que consiste en cambiar la óptica y la retórica que es propia a ciertos acontecimientos, es una de las performances lingüísticas características de aquellos colectivos que deben enmascarar sus visiones de mundo, sus quejas y sus críticas por medio del humor, la parodia, la tergiversación y la inversión. De modo que, desde el título del cuento, esta narración aboca al público lector a una cosmovisión sobre Lima en constante desplazamiento. Con ello se genera una multiplicidad de significados imposibles de sintetizar en una única imagen o concepto $^{22}$.

Volviendo a la escena en que la voz narrativa dibuja el ambiente que se vive en las corridas de toros de Acho, esta se inscribe, en principio, siguiendo la aparente idealización de Lima. El coso se erige como ese lugar ciudadano donde es posible reunir a una gran diversidad de grupos sociales. Sin embargo, también es ese espacio donde se muestra el descontrol limeño, pues "[e]l pueblo enloquece para dirigirse a la plaza histórica"; y al igual que "[c]irculan las butifarras, el agua de berro, el emoliente", también lo hace el "doctor" (Matto de Turner, 2015, pp. 150-151). Esta concisa serie de sustantivos da cuenta de la "pérdida de juicio" del "pueblo" ante la buena labor de un torero y proporciona otra visión de Lima distinta a las precedentes en tanto que es portadora de una crítica al comportamiento del "pueblo". Es decir, si los suicidios y las limeñas sirven para criticar las actitudes de esa Lima de las clases media-alta, la plaza de Acho es 
el escenario urbano que le permite a Matto de Turner incorporar un discurso que denuncia el descontrol popular en estas celebraciones donde se incluye el conjunto total de la sociedad limeña.

Las distintas imágenes sobre Lima mantienen una relación especular con los acontecimientos de la vida del protagonista (ansia de triunfo, triunfo, fracaso sentimental, intento de suicidio y triunfo del amor). Con todo, es necesario señalar que los elementos más productivos, desde una perspectiva cultural, se encuentran en los procesos que Francisco Ccolqque-Paco de Plata lleva a cabo para ser mercancía y sujeto limeño y en las inconcreciones raciales con que la voz narrativa lo caracteriza. Es este último aspecto el que abordaré en primera instancia, ya que en él se encuentra una ideología racial-nacional que contradice, en parte, la aparente apuesta por un protagonista racial y culturalmente mestizo.

Ante la pregunta de dónde ubica culturalmente la voz narrativa a este personaje, la respuesta es, por lo menos, ambigua. La voz narrativa no construye un sujeto con identidad cultural indígena o mestiza, sino que lo describe como producto de un clima y una geografía al afirmar que "Francisco Ccolqque nació en las faldas de un nevado perpetuo, recibiendo de la naturaleza el carácter tétrico reconcentrado, casi frío; pero al salvar las colinas y llegar a la pampa sintió el fuego de la sangre andaluza" (Matto de Turner, 2015, p. 148). Es más, la descripción física que la voz narrativa proporciona de Francisco es la siguiente:

Magnética era la fuerza de su pupila negra, puesta en ojos grandes y rasgados, sombreados doblemente por largas pestañas y por arqueada ceja.

Bucles castaños rizados como la onda del lago, y empolvados por la tierra, caían en graciosa melena sobre su hombro adornando su cabeza, a la que servían de pedestal, magnífico talle esbelto y porte aristocrático. (Matto de Turner, 2015, p. 148)

Es evidente que el cuerpo que se describe no es indígena. Puede argumentarse que Matto de Turner participa de la visualidad tan propia de los románticos americanos que diseñaban los cuerpos otros-étnicos con los parámetros estéticos de belleza europeos, como estrategia de prestigiar las 
culturas que representaban. Sin embargo, si a esta descripción corporal se le suma la cita previa, se ve cómo ambas convergen para presentarnos un serrano donde no domina lo indígena peruano sino su "sangre" andaluza.

La negociación cultural que la voz narrativa lleva a cabo con este personaje pone de relieve, consciente o inconscientemente, un conjunto de características que se creen necesarias para que el serrano logre "conquistar" Lima: ser decidido, tener ambición, no parecer "indio" físicamente y tener el coraje de "vencer o morir", como Francisco Ccolqque le dice al general cuando se enlista en el Ejército (Matto de Turner, 2015, p. 149). Con relación a este aspecto de la narración, parece que Matto de Turner propone una variante de la arquetípica masculinidad del self-made-man adaptada a las condiciones socioétnicas y socioculturales peruanas. De hecho, también Francisco Ccolqque parece consciente de que la primera transformación a que debe someterse, si quiere conseguir la tan ansiada gloria en Lima, es desprenderse de su parte indígena. Así se constata cuando la voz narrativa afirma que Francisco "al llegar a Lima ha traducido en Plata su apellido indígena”, y que, tras lograr la admiración por su faena, "recibió el bautismo del público para ser su ídolo. // Paco de Plata" (Matto de Turner, 2015, p. 151; cursivas del original). El sincretismo con que Matto de Turner gestiona el proceso de transculturación que lleva a cabo Francisco Ccolqque-Paco de Plata pone de relieve las características que el varón peruano de esta extracción social, étnica y geográfica debía de ostentar para triunfar en Lima. En consecuencia, la configuración físico-psicológica de tipo nacional, que Matto de Turner diseña en este protagonista, es tanto un modelo de masculinidad ideal para la nación imaginada y deseada como la evidencia del prejuicio racial y cultural latente que muestra las dudas ante las posibilidades de incorporar a los sujetos culturales indígenas a la nación ${ }^{23}$.

En aparente contradicción con la imagen de self-made-man que de Paco de Plata se ha creado hasta el final de la segunda parte del texto, en la tercera se nos presenta un hombre triste, desesperado y dispuesto al suicidio. La fuerza de la naturaleza que era Francisco Ccolqque-Paco de Plata se ha transformado en una 
variante del descreído que aparece en el epígrafe de este trabajo. El cambio se debe a que no es correspondido por la mujer que ama, Paulina Laredo. Es en esta instancia argumental donde se localiza el potencial transformador de la "limeña" y donde se quiebra el imaginario del self-made-man hegemónico. De hecho, la masculinidad de Paco de Plata forma parte de una cosmovisión sociosexual donde se desea una sentimentalidad masculina que funcione como puente de unión con las feminidades que se instauran en este universo del sentimiento.

Dicha descomposición de la ideología hegemónica del self-made-man está en perfecta consonancia con la ideología de género que analicé en "Pálida!". Desde la cosmovisión autoritativa de ambos cuentos, una masculinidad, y por extensión una nación, exitosa social y éticamente no es posible sin una feminidad que comparta una misma cosmovisión ético-sentimental. Por lo tanto, el potencial de modernidad de los discursos sobre género se encuentra en Paulina Laredo, no en Paco de Plata ${ }^{24}$. Es ella quien tiene la capacidad de modernizar la política sentimental y matrimonial limeña-nacional. Así, Paulina Laredo, ante un Paco de Plata que se ha dejado cornear sin vacilar porque ella no le correspondía, rompiendo todo protocolo y todas las convenciones de la educación femenina de su clase, se arroja "desde la galería" mezclándose "con la multitud que recoge el cuerpo ensangrentado del torero" (Matto de Turner, 2015, p. 151) para estar junto a él. A partir de este momento, la voz narrativa convierte a Paulina Laredo en la heroína ideológica del texto, pues es ella quien, por amor y porque sabe reconocer los valores que han llevado a Paco de Plata al intento de suicidio, rompe las barreras de clase, cultura y, tal vez, raza. Si bien, como en las anteriores instancias disruptivas de los discursos hegemónicos, la voz narrativa desdibuja su posición ideológica ante la desobediencia a las normas sociosexuales de Paulina Laredo. El enmascaramiento de la modernidad ideológica de esta protagonista la lleva a término la voz narrativa por medio de la elaboración de una analogía entre la actitud de Paulina Laredo con la manera de ser de la mujer limeña que se había presentado al inicio del texto (ser grande y heroica en las grandes ocasiones / ser una niña en la cotidianidad), al exclamar: "Las aberraciones de la mujer son infinitas, como su ternura" (Matto de Turner, 2015, p. 152). Ante estas constantes 
contradicciones respecto de cómo interpretar la actitud de la protagonista, es el público lector quien debe decidir cómo considerar la acción de Paulina Laredo, si como un acto sublime o como una niñería.

Quizá esta instancia sea uno de los momentos narrativos con más potencial de diversidad de interpretación. En una primera instancia, la protagonista podría ser percibida como una aberración para aquellos lectores que pensaran que había actuado impropiamente, pero que era digna de perdón porque actuó llevada por el impulso casi caritativo de salvar al torero del suicidio. Para otros grupos lectores podría ser el ejemplo perfecto que mostraba que las mujeres eran y estaban dominadas por las emociones. En cuyo caso, también esta feminidad era perdonada por no subvertir la ideología de género hegemónica. Incluso, para otros colectivos ideológicos, el texto podría interpretarse en una combinación de las dos anteriores visiones de género: las mujeres son seres que se dejan dominar por los sentimientos y deben permanecer fuera de la esfera pública. Sin embargo, para un potencial público lector que defiende una feminidad más activa individual y nacionalmente, Paulina Laredo podría representar una forma de feminidad que adquiere agencia a partir de una interpretación muy libre de la codificación genérica de la sentimentalidad femenina. Es en esta lectura donde se hace evidente el carácter innovador y moderno de Paulina Laredo. De todos modos, sea cual sea la lectura que se privilegie, la perturbación a la norma de comportamiento se ha establecido y se ha hecho con ese tono ligero, alegre, lleno de picardía erótica que implica nuevos agenciamientos para las mujeres ${ }^{25}$.

Con todo, Matto de Turner sigue encubriendo y desdibujando la ruptura que ha llevado a cabo con Paulina Laredo. La operación de enmascaramiento es insistir en el protagonismo de Francisco Ccolqque-Paco de Plata al final de la narración con la siguiente afirmación: "Pero la verdad es que el amor tiene héroes aun en las clases desheredadas de los grandes pueblos" (Matto de Turner, 2015, p. 152). Con este final, esta escritora ha confeccionado un conjunto de tachaduras a los aspectos más problemáticos del texto en aras de promover una pareja heterosexual que le permita socavar las estrictas reglas de las políticas 
matrimoniales del momento y los códigos sociosentimentales asignados a hombres y mujeres. En este final se silencia todo juicio al intento de suicidio de Paco de Plata; se plantean así unas posibilidades de cambio por medio del desacato femenino a la convención social pero ambiguamente lo desaprueba, se crea una masculinidad que llena las expectativas amorosas de una mujer y convierte al hombre que ostenta esa masculinidad en un héroe nacional sentimental no limeño. En tal sentido, quien salva a esta masculinidad heroica del descreimiento y de la muerte es Paulina Laredo. Es más, la que debe confrontar a la sociedad, como se percibe en la conversación con sus amigas, es ella, como es ella también la que es capaz de ser moderna al aceptar como esposo a un hombre de clase y cultura distintas a la suya. De ahí que ante la pregunta de dónde ubicar el proyecto de modernidad y de reforma ético-nacional, la respuesta sea en la feminidad que encarna Paulina Laredo.

Las transacciones, inestabilidades, paradojas y contradicciones ideológicas presentes en estos dos cuentos respecto a la modernidad, a las políticas de género y a los proyectos de refundación nacional son las estrategias que enmascaran la inscripción de un conjunto de saberes estratégicos que imaginan nuevos agenciamientos ideológicos para las mujeres de las clases altas-medias. Ahora bien, estos textos, como el significado que se le dé a dichas tensiones ideológicas, admiten una gran variedad de lecturas que, como sostiene Andreas Huyssen (2006),

[...] dependen, entre otros factores, tanto de la ideología de la lectora/ lector como de las posibilidades analíticas y teóricas que se han abierto en los procesos intelectuales históricos. Además, estas recepciones distintas están marcadas por los intereses de los receptores individuales, determinados por la edad, el origen de clase y las contradicciones de conciencia. (p. 247)

Así, el haber elegido un marco ideológico feminista para el análisis de estos dos cuentos ha hecho hincapié en la capacidad disruptiva de estos respecto a los imaginarios hegemónicos sociosexuales. Estos procesos de alteración de 
las normas genéricas ponen de manifiesto el poder cultural con el que se invistió Matto de Turner para proponer unas masculinidades y feminidades que operaban como sujetos-objetos desestabilizadores de los discursos de poder del periodo en sus aspectos sociogenéricos, a la vez que funcionaban como pilares éticos para la refundación nacional.

\section{Notas}

1 Entre los muchos estudios sobre Aves sin nido he tenido en cuenta: Literatura y sociedad en el Perú: La novela indigenista (2005), de Antonio Cornejo Polar; "Clorinda Matto de Turner y el ángel del hogar” (1990), de Joan Torres-Pou; Lágrimas andinas (2005), de Ana Peluffo; y "Clorinda Matto de Turner, novelista y los aportes de Antonio Cornejo Polar al estudio de la novela peruana del siglo XIX" (2005), de Rocío Ferreira.

2 Los estudios que he consultado para la elaboración de este ensayo respecto a la labor de Matto de Turner como periodista y directora de periódicos son: "Writing for Her Life. The Essays of Clorinda Matto de Turner" (1995), de Mary Breg; “'Don't Interrupt Me'. The Gender Essay as Conversation and Countercanon" (1995), de Mary Louise Pratt; y El abanico y la cigarrera. La primera generación de mujeres ilustradas en el Perú (2005), de Francesca Denegri.

3 Carolina Ortiz Fernández (2018), lleva a cabo un importante estudio en el que pone de relieve la importancia que Matto de Turner le daba al periodismo, ya que según esta estudiosa para la escritora cusqueña "[...] el periodismo constituía una tarea pedagógica que debía contribuir a despertar la conciencia cívica, con las consiguientes virtudes morales y el compromiso con el país" (p. 105).

4 Los estudios a que hago referencia son "Modelos de viajera: Clorinda Matto de Turner y su 'viaje de recreo"” de Vanesa Miseres (2013); y "Cortar el nudo. Los relatos de viaje de Maipina de la Barra, Clorinda Matto de Turner y Eduarda Mansilla" de Francesca Denegri (2017).

5 Una aproximación distinta la presenta Thomas Ward $\left(2002^{\mathrm{a}}\right)$ en "La ideología nacional de Clorinda Matto de Turner".

6 La ideología romántico-idealista hizo de la literatura un medio para configurar imaginarios de comportamiento deseados, alejándose de los proyectos realistas que creaban microcosmos sociales para exponer los vicios y problemas de una sociedad determinada. De hecho, esta es la macro ideología con que se diseñaron las teorías de las novelas nacionales latinoamericanas en las décadas de los cincuenta y sesenta en muchos de los países hispanoamericanos, no obstante dicho proyecto había sido contestado a finales de siglo XIX. En el caso de Perú, no es solo González Prada quien propone una nueva forma de concebir la novela y su función social, sino también Mercedes Cabello de Carbonera (1889), en su prólogo a Blanca Sol, y la misma Matto de Turner (1895) en su prólogo a Herencia. 
7 “Pálida!... Pero es ella...!" se encuentra en Leyendas y recortes (Matto de Turner, 1893, pp. 57-66). Esta es la edición que utilizo. A partir de ahora el texto aparecerá citado como "Pálida!". "Amor de redondel" se publicó en el segundo tomo de Tradiciones cuzqueñas. Leyendas, biografias y hojas sueltas (Matto de Turner, 1884). Sin embargo, utilizo la edición de este cuento que se encuentra en Antología literaria 3, preparada por el Ministerio de Educación en 2015 (pp. 148-152). Ambos cuentos salieron publicados con anterioridad en El Perú Ilustrado.

8 Foucault (2007) conceptualiza los discursos de poder-verdad; dice: “[...] el poder produce, produce realidad, produce dominio de objetos y rituales de verdad. El individuo y el conocimiento que puede ser obtenido de él pertenece a esta producción" (p. 194).

9 Ana Peluffo (2007) examina las distintas masculinidades en competencia del periodo.

10 El proyecto de Matto de Turner coincide plenamente con el del Círculo Literario, como argumenta Friedhelm Schmidt-Welle (2001), ya que ambos quieren "[...] fundar una literatura nacional con sus propios temas y su propia estética que reflejen la realidad histórica, por una parte, y contribuir al mejoramiento de las costumbres cumpliendo una pedagógica, por otra" (p. 136).

11 Jorge Luis Camacho describe este tipo de representación de la feminidad como "[f] iguras enigmática prontas a morir" (2001, p. 351). Relevante también para el estudio de este arquetipo de feminidad es "Decadentismo y necrofilia: el culto a la amada muerta en la poesía latinoamericana de fin de siglo", de Ana Peluffo (2003).

12 Thomas Ward (2002b) define el nihilismo como la "[...] negación de todo grupo de valores (de los principios religiosos, políticos y sociales" (p. 514). Sin embargo es cierto que Matto de Turner, en Aurelio, no crea un decadentista. Relevante también para una visión distinta sobre la ideología nacional de Matto de Turner es "Feminismo liberal vs anarquismo radical. Obreras y obreros en Matto de Turner y González Prada, 1904-1905" (Ward, 2009), del mismo autor. En este artículo, Ward propone que la ideología de esta escritora podría denominarse "krausopositivismo", puesto que imbrica la propuesta krausista de un racionalismo armónico, a la vez que concibe la sociedad como un organismo, tal y como lo propone la teoría sociopolítica positivista (pp. 8-10).

13 El uso estratégico de Matto de Turner de un vocabulario cuyo campo ideológico se asocia con la religión es importante porque con la elección de un vocabulario "tradicional", alejado de los neologismos propios de ciertas modernidades, es posible llegar al público lector al que esta escritora dirigía su creación. A su vez, combina este campo semántico con el de la innovación, con el neologismo producto de los avances científicos. Es decir, lo que parece una tensión es una negociación en la que se entrelazan armónicamente, siguiendo la propuesta de Ward (2002), dos cosmovisiones aparentemente irreconciliables: tradición y ciencia. De hecho, parece que Matto de Turner había hecho suya parte de la teoría propuesta por Blest Gana en 1861. Blest Gana exigía una literatura nacional que no se propusiera competir con la producción 
europea, sino producir textos que hablaran de realidades nacionales. Para ello debía hacer uso de un registro lingüístico que llegara al mayor número de personas. La información aquí expuesta la he tomado del estudio de Juan Poblete (1999), "La construcción social de la novela y la novela social: el caso chileno” (pp. 93-95).

14 Desde la alteración a los valores ideológicos que pueden analizarse en este cuento, me parece interesante apuntar cómo la cámara oscura en que trabaja Aurelio es una inversión del espacio gótico. El proyecto de Aurelio de conseguir captar a través de la fotografía la imagen de Esperanza es presentada por la voz narrativa como una clara inversión de la reacción del doctor Frankenstein ante su creación, en Frankenstein. The Modern Prometheus (1818) de Mary Shelley, como puede verse en la siguiente cita: "Su afán recuerda el del genio que, persiguiendo elaborar un ser viviente con los componentes del hombre, oyó, de repente, en la retorta: mon pere! Cayendo el padre desmayado de placer" (Matto de Turner, 1893, p. 65).

15 Para esta interpretación me baso en las propuestas sobre lo fantástico de David Roas (2010). Para él “[...] lo fantástico es una categoría que nos presenta fenómenos que suponen una transgresión de nuestra concepción de lo real, la cual, dejando aparte cuestiones ontológicas o puramente científicas, hemos desarrollado en función de unas regularidades, de unas 'certidumbres preconstruidas' que nos permiten modificar lo posible y lo imposible. A partir de ellas, hemos construido unos límites que nos separan de lo desconocido, de lo amenazante. El objetivo de lo fantástico es precisamente desestabilizar esos límites, subvertir esas convenciones colectivas antes descritas, en definitiva, cuestionar la validez de los sistemas de percepción de la realidad comúnmente admitidos" (p. 18). El carácter perturbador de lo social que tiene lo fantástico es precisamente lo que está ausente de este cuento de Matto de Turner. Más bien al contrario, la perturbación de la realidad objetiva posibilita el restablecimiento de un proyecto de masculinidad deseada para la regeneración nacional.

16 El apartado en que estoy centrando mi análisis es el siguiente: "La plancha sensibilizada había copiado una especie de gaza flotante que cruzó en dirección a los cielos, cuya presencia hizo estremecerse suave y misteriosamente el organismo del fotógrafo, cual si una nube de mentol le rodeara; y contemplando en la cámara oscura una imagen incolora, sufrió el vértigo de la dicha, el miedo, la sorpresa, la desesperación. Todo junto y mezclado, articulando en el colmo de la confusión: 'Pálida!... pero es ella!... Dios mío, creo en ti'. Aurelio tenía en sus manos el retrato de Esperanza” (Matto de Turner, 1893, p. 67).

17 Por "limeñas" el texto entiende el colectivo de mujeres de clase media-alta capitalinas.

18 Algunos aspectos que aparecen en esta narración van a constituir la cosmovisión urbana que Matto de Turner va a desarrollar años más tarde en Índole (Matto de Turner, 1891) y Herencia (Matto de Turner, 1895). Carolina Ortiz Fernández (2007) aborda las novelas antes mencionadas desde una perspectiva teórica sociológica donde destaca "[...] la vida cotidiana, los estilos de vida de diversos grupos sociales y clases sociales" (pp. 382-383). De hecho, el subtítulo de este cuento, "a modo de novela", hace referencia al proyecto realista de creación de un microcosmos en las ficciones narrativas. 
19 La distinción entre gringos y chinos remite al rechazo y discriminación de que eran objeto las comunidades de inmigrantes asiáticos en el Perú de este periodo.

20 La parte del texto a que hago referencia es la siguiente: "Lima comenta con ternura un balazo, que un gringo se aplica como portante al otro mundo, y se lastima cuando un chino se balancea ahorcado por su propia mano para viajar a Tonquín; mas, luego, la Mascota o Bocaccio, la alegre romería de la Exposición, o el alegre listín de los toros le cambian la escena, y le varían el sentimiento. La gran capital encierra el Perú, donde se condensa el bullicio de toda la República" (Matto de Turner, 2015, p. 149; cursivas del original).

21 Desde las convenciones narratológicas, el título de una obra pertenece a la persona que escribe el texto. Esta instancia muestra la coincidencia ideológica de la voz narrativa con la autoral.

22 En lenguaje taurino, redondel es la plaza de toros. Así, el título lo que viene a decir es que es un amor de plaza de toros. El tono jocoso e incluso irónico del título se hace evidente al sustituir los términos.

23 Thomas Ward (2002a) presenta una propuesta sobre la ideología racial de Matto de Turner.

24 La simbología que "la mujer" adquiere en los discursos de modernidad es, desde la perspectiva feminista de Rita Felsky (1995), compleja debido a que asume sentidos contradictorios entre sí: la tradición y la costumbre, por un lado, y la más atrevida modernidad por otro (pp. 2-8). En "Amor de redondel" la que ostenta la capacidad de innovación social es, sin lugar a dudas, Paulina Laredo, sin por ello dejar de ser una feminidad en apariencia tradicional.

25 Nótese que el título se toma de la inscripción que Paulina Laredo hace del amor que comparte con Paco de Plata. Es decir, en esta lectura, la protagonista ideológica es una forma de amor "moderno", producto del espacio urbano más democratizado que ha presentado el texto: la plaza de Acho.

\section{Referencias bibliográficas}

Berg, M. G. (1995). Writing for Her Life. The Essays of Clorinda Matto de Turner. En D. Meyer (Ed.), Reinterpreting the Spanish American Essay, Women Writers of the $19^{\text {th }}$ and $20^{\text {th }}$ Centuries (80-89). Austin: University of Texas Press.

Caballero Wangüemert, M. (1993). Clorinda Matto de Turner: el papel de la mujer entre la tradición y la innovación. En L. Fleming y M. T. Bosque Latra (Eds.), La crítica literaria española frente a la literatura Latinoamericana (159-174). Ciudad de México: UNAM. 
Cabello de Carbonera, M. (1889). Blanca Sol. Lima: Imprenta y Librería del Universo de Carlos Prince.

Camacho, J. L. (2001). El cirujano y la enferma: la representación de la mujer en la literatura modernista. Revista Canadiense de Estudios Hispánicos, 26(1-2), 351-360.

Clúa Ginés, I. (2014). Las que regresan. Rastros y rostros de lo espectral en El primer loco. En R. Álvarez; A. Angueira y M. C. Vilavedra, Rosalía de Castro no século XXI. Unha nova ollada (956-973). Santiago de Compostela: Consello da Cultura Gallega.

Cornejo Polar, A. (2005). Literatura y sociedad en el Perú: La novela indigenista. Lima: CELACP, Latinoamericana Editores.

Denegri, F. (2005). El abanico y la cigarrera. La primera generación de mujeres ilustradas en El Perú. Lima: Instituto de Estudios Peruanos, Centro de Estudios de la Mujer Peruana Flora Tristán.

Denegri, F. (2017). Cortar el nudo. Los relatos de viaje de Maipina de la Barra, Clorinda Matto de Turner y Eduarda Mansilla. Revista Chilena de Literatura, 96, 29-54. Recuperado de https://revistaliteratura.uchile.cl/ index.php/RCL/article/view/47577/49953.

Felsky, R. (1995). Gender of Modernity. Cambridge: Harvard University Press.

Ferreira, R. (2004). Amores traicionados, pasión, género, etnicidad y nación en las leyendas y dramas andinos de Clorinda Matto de Turner. En G. Hintze, Escritura femenina: diversidad y género en América Latina (75-95). Cuyo: Editorial de la Facultad de Filosofía y Letras de la Universidad Nacional del Cuyo.

Ferreira, R. (2005). Clorinda Matto de Turner, novelista y los aportes de Antonio Cornejo Polar al estudio de la novela peruana del siglo XIX. Revista de Crítica Literaria Latinoamericana, 31(62), 27-51. Recuperado de https://as.tufts.edu/romancestudies/rcll/pdfs/62/4-FERREIRA.pdf.

Foucault, M. (2007). Historia de la sexualidad. Voluntad de saber. Traductor Ulises Guiñazú. Ciudad de México: Siglo Veintiuno Editores.

Huyssen, A. (2006). Después de la gran división. Modernismo, cultura de masas, posmodernismo. Traductor Pablo Gianera. Buenos Aires: Adriana Hidalgo Editora. 
López Martín, D. (2007). El espiritismo, la parapsicología y el cuento fantástico hispanoamericano del siglo XIX. Arrabal, 5-6, 39-46. Recuperado de https://www.raco.cat/index.php/Arrabal/article/view/140506/192078.

Matto de Turner, C. (1884). Tradiciones cuzqueñas. Leyendas, biografias y hojas sueltas. Lima: La Equitativa.

Matto de Turner, C. (1891). Índole (Novela peruana). Lima: TipoLitografía Bacigalupi, 1891.

Matto de Turner, C. (1893). Leyendas y recortes. Lima: La Equitativa.

Matto de Turner, C. (1895). Herencia (Novela peruana). Lima: Imp. Masías.

Matto de Turner, C. (2015). Amor de redondel. Cuento a modo de novela. En Minedu, Antología literaria 3 (148-152). Lima: Ministerio de Educación. Recuperado de https://docplayer.es/73314095-antologia-literaria-3.html

Miseres, V. (2013). Modelos de viajera: Clorinda Matto de Turner y su "viaje de recreo". Chasqui: Revista de Literatura Latinoamericana, 42(2), 11024.

Ortiz Fernández, C. (2007). El pensamiento político de Clorinda Matto de Turner. Investigaciones Sociales, 8(XI), 379-387. doi: 10.15381/is.v11i18.7151.

Ortiz Fernández, C. (2018). El Recreo, tribuna pública de mujeres pioneras en la educación y el periodismo en el Perú del siglo XIX. Letras, 89(130), 100-122. doi: 10.30920/letras.89.130.5.

Peluffo, A. (2003). Decadentismo y necrofilia: el culto a la amada muerta en la poesía latinoamericana de fin de siglos. En Schmidt-Welle, F. (Ed.), Ficciones y silencios fundacionales. Literaturas y culturas poscoloniales en América Latina (siglo XIX) (239-256). Madrid: Iberoamericana Vervuert.

Peluffo, A. (2005). Lágrimas andinas: Sentimentalismo, género y virtud republicana en Clorinda Matto de Turner. Pittsburgh: Instituto Internacional de Literatura Latinoamericana.

Peluffo, A. (2007). Dandies, indios y otras representaciones de la masculinidad en Manuel González Prada. Revista Iberoamericana, 73(220), 471-486. doi: 10.5195/reviberoamer.2007.5339. 
Poblete, P. (1999). La construcción social de la novela y la novela social: el caso chileno. Latin American Research Review, 34(2), 75-108.

Pratt, M. L. (1995). "Don't Interrupt Me", The Gender Essay as Conversation and Countercanon. En D. Meyer (Ed.), Reinterpreting the Spanish American Essay. Women Writers of the $19^{\text {th }}$ and $20^{\text {th }}$ Centuries (11-26). Austin: University of Texas Press.

Roas, D. (2010). La risa grotesca y lo fantástico. En A. Gimber y M. Goicoechea (Eds.), Espacios y tiempos de lo fantástico. Una mirada desde el siglo XXI (17-30). Bern: Peter Lang.

Schmidt-Welle, F. (2001). Harriet Beecher Stowe y Clorinda Matto de Turner: escritura pedagógica, modernización y nación. Iberoamericana, 4(1), 133-176.

Torres-Pou, J. (1990). Clorinda Matto de Turner y el ángel del hogar. Revista Hispánica Moderna, 43(1), 3-15.

Velázquez Castro, M. (2012). La narrativa breve de Clorinda Matto de Turner: de la tradición y leyendas románticas al cuento modernista. Escritura y Pensamiento, 12, 75-103.

Velázquez Castro, M. (2017). Biotecnologías novelísticas en la región andina (1840-1905). Lectura y cuerpo. (Tesis para optar el grado académico de Doctor en Literatura Latinoamericana). Universidad Andina Simón Bolívar, Quito, Sede Ecuador. Recuperado de https://bit.ly/2UHTePG.

Ward, T. (2002a). La ideología nacional de Clorinda Matto de Turner. Neophilologus, 86(3), 401-415. doi: 10.1023/A:10156112.

Ward, T. (2002b). Los posibles caminos de Nietzsche en el Modernismo. Nueva Revista de Filología Hispánica, 50(2), 2002, 489-515. doi: 10.24201/ nrfh.v50i2.2191.

Ward, T. (2009). Feminismo liberal vs. anarquismo radical. Obreras y obreros en Matto de Turner y González Prada, 1904-1905. A Contracorriente, 7(1), 118-211. 